\title{
ONLINE FINANCE: REGULATORY REGIME REFORM IN CHINA
}

\author{
Yang Liu*
}

\begin{abstract}
Online finance now in China has been dramatically progressed. The online finance has the functions like financial service, investment broker and electronic banking platform; meanwhile it has technical mobility, virtual transactions and strongly internet dependency. The regulation on the online finance in China, which has shown its disadvantages and brought legal risks, has the same model as other regulations on the traditional business services. Therewith, a new model regulation is demanded to change the separated regulation frameworks, to establish unified information and transaction networks and to provide the preconditions of online finance tax.
\end{abstract}

INTRODUCTION 328

\section{GENERAL INTRODUCTION: ECONOMIC AND PHYSICAL CHARACTER OF}

ONLINE FINANCE

A. Economic Character of Online Finance ……............................ 329

B. $\quad$ Physical Character of Online Finance .................................... 330

II. PROBLEMS IN THE ONLINE FINANCE MARKET …….................................330

A. Problems of Internet and Information Security ........................ 330

B. $\quad$ Problems of Market and Business Regulations .......................... 330

III. RECOMMENDED TOP DESIGN OF ONLINE FINANCE REGULATION............332

A. Construction of National Wide and Unified Online Finance

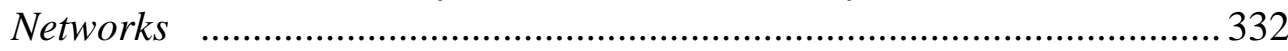

B. $\quad$ Establishment of Incorporated Regulatory Authorities.............332

C. A Specified Tax Rate of Online Finance ......................................333

CONCLUSION.

\section{INTRODUCTION}

Online Finance in China has been dramatically progressed during the past. It has the functions like financial service, investment broker and electronic banking platform; meanwhile it has technical mobility, virtual transactions and strongly internet dependency. However, the traditional financial market regulations in China cannot meet the market developments.

\footnotetext{
${ }^{*}$ Lecturer Dr. jus., Add: B9-Noth 404, South China University of Technology, Law School, High Education Centre South, Guang Zhou, China PR. Lecturer Dr. jus. Yang Liu is also a Post Doctor of the Law Institute, China Academy of Social Science. Research fields: Regulatory Laws.

This research was financially supported by the National Science Foundation.
} 
Most problems are the fragmentation of the regulatory authorities. Therefore this paper is to investigate the economic character of the online finance and to give a possible recommendation of the regulatory regime reform in China.

\section{GENERAL INTRODUCTION: ECONOMIC AND PHYSICAL CHARACTER OF ONLINE FINANCE}

Associated with the development of internet services, the online financial service has created a market by itself, because money lenders and borrowers can meet together through the internet. Online finance is characterized with the P2P (peer to peer lending). The P2P in China, which is mainly to serve for the demands of small and countryside businesses and has taken the function of the banks to provide flexible financial services. Now the P2P market scale is about 20 to 40 billion RMB with annual development rate of $300 \%$. But for this business, a specified regulation has not been given: There are no legal market entrance preconditions and no detailed business standards to supervise the market.

\section{A. Economic Character of Online Finance}

According to the analysis, market of the online finance has at least three economic characters: First, the online finance, like the P2P, is a kind of broker platform. On this platform, money lenders will legally buy the wealth management products sold by the company. Then the money will be formulated into an investment in a certain project, and this investment will be calculated as a financial means to the debtor.

Second, in the practice the online finance company is generally registered as an investment consulting company or an e-business company, because the registrations of such kind of companies are much easier than the registration of a financial enterprise, in accordance with the Chinese Company Law. However, businesses of an online finance company are identical with the businesses of financial enterprise, which include asset management, risk assessment, risk management, analysis of the credit information, financing and banking.

Third, according to the Chinese Company Law, investment consulting company or e-business company is not permitted to do business of financing. Thus, the online finance companies have to face some uncertainties in the legal environments. 


\section{B. Physical Character of Online Finance}

Besides the character online finance market, the online finance has also its physical characters with the following three aspects. First, online finance has strong mobility. The internet service has provided that the online finance would have various transactional means (like trust investment, stock exchange, foreign currency exchange, etc.) to increase its business profits. Meanwhile through the telecommunication networks, the business profits would be transferred immediately to the place, where the investors want to.

Second, online finance is concretized with virtual transactions, which could be seriously affected by the online information. Thus, transparency and accuracy of information are decisive to the security of investments and the interests of investors.

Third, internet dependency is a disadvantage of online finance. Without internet service, the online finance cannot be accomplished; the security of internet service is absolutely predominated to the online financing.

\section{PRoblems IN THE ONLINE FinANCE MARKET}

\section{A. Problems of Internet and Information Security}

The internet security is now a top issue in the international relationships. As released by the media, the US government has taken the advantages of internet technology to control the global internet services. In China, the online finance will be therefore jeopardized, when the foreign government to overuse its power. For this reason, China needs to construct its own safeguarded internet networks.

Meanwhile, in China the online information is just supervised by the Chinese government indirectly. That means that the website company has the right of self-regulation firstly, which is under the supervision of a regulatory authority. This supervision system is not well functional. A lot of forged information now is released, with which investors cannot really judge and predicate the security of their investments. Additionally, in the Chinese financial market regulation mechanism, different authorities will not share the information they have, which causes the market administration to be unsystematic.

\section{B. Problems of Market and Business Regulations}

Regulation on the online finance in China is inefficient. As mentioned before, the online finance uses internet as its tool of business transactions, 
which has good flexibility and strong mobility. However, the market regulator, for example the tax bureau, does not have the same technical capacities. This technical shortage of the charging bureau makes it impossible that all information of the online financial transactions and related business information would be uncovered by the regulatory authorities. Without the information, regulators will be unable to control the market.

The compartmentalization of market administrations ${ }^{1}$ is unfit for the online business regulation. It has been notified that the online finance has the economic functions like investment broker or banking platform. The business of an online finance company shall therefore be supervised by several bureaus in accordance with the Chinese economic laws, including the tax bureau, the bank supervision agency, state administration of foreign exchange, the stock exchange supervision agency, etc. For those bureaus, the market administrations, however, are separated into several isolated fragments, which are charged by just a single bureau. And there is no legal cooperation among those agencies and bureaus. Even the related information will not be changed among those charging bureaus, which makes the market regulation more complicated and inefficient.

The traditional procedure of tax declaration of a company ${ }^{2}$ now is unfit also for the new online business model. The online business information, including the taxable income, will be easily hided, because generally the online transactions, which are just concretized with digital data, are done without paper. Therewith, the tax bureau cannot accurately judge, whether the information provided by the online finance company is correct, because it cannot collect the necessary evidences accurately.

Additionally, a specified tax rate of the online finance is not provided legally yet. The online finance company will only pay the business tax like other investment consulting company or e-business company. But in accurate, the tax rate of investment consulting or e-business is unfit for the business of online finance, which tightly depends on the universal service of telecommunications provided by the state. As the online finance company has taken more advantages of the telecommunication services than other companies, the universal service investments could also be regarded as the governmental subsidy to the online business. Thus, settlements of the tax rate should pay attention to the market reality, and a specified tax rate of the online finance shall ensure that the usage of public telecommunication networks would be compensated. The governmental investments in the

\footnotetext{
${ }^{1}$ Yang Liu, Cost Oriented Grid Charge - Legal Comparison of the EU, German and Chinese Energy Laws, AVM MuNICH 126 (2012).

${ }^{2}$ Yang Liu, Electricity Price Regulation in the EU, Germany and China, AVM MuNICH 175 (2013).
} 
universal service could then be repaid.

As a conclusion, problems of the market and business regulation incur that there are still some "black holes" in the online finance regulations in China, which ought to be reformed and need a new top design.

\section{RECOMMENDED TOP DESIGN OF ONLINE FINANCE REGULATION}

In order to ensure the safety of our national financial system and accelerate the positive progress of online finance, the current regulatory mechanism should be reformed and a new top design should be thereafter established ${ }^{3}$. According to the economic and physical characters of the online finance, the recommended top design should include the following issues:

\section{A. Construction of National Wide and Unified Online Finance Networks}

One of the problems in the online finance market is the security of internet networks and its service, since the internet could be manipulated by the foreign government. The most efficient solution is to construct our own national internet networks, which can provide a safeguarded network service and will be supervised by the administrative authorities. At the same time, tax bureau and the other governmental departments will be able to monitor the information of online business, when it is necessary. The efficient and safety of such kind of market supervision will ensure that all illegal transactions through the networks would be found quickly.

Moreover, trade secret shall be isolated from the open access to the networks ${ }^{4}$. It means that the usage of the information from the government will be limited. Trade secrets and the other information, which the online finance company does not want to release to the public, will be protected by the empowered authorities.

\section{B. Establishment of Incorporated Regulatory Authorities}

As mentioned above, the compartmentalization of market regulations causes the difficulties of market supervision and decreases the efficiency of governing. The change of traditional finance market brings us the opportunity to reform our old mechanism of market control into a modernized and flexible system. The modernizations of regulation will implement different methods to

\footnotetext{
${ }^{3}$ Yang Liu, On the Possibility to Replace Ladder-type Price with Electricity Consumption Tax, 12(1) JOURNAL OF NANJING UNIVERSITY OF TECHNOLOGY 56 (2013).

${ }^{4}$ Yang Liu, Research of the Direct Power Purchase in China, Journal of China University of Geosciences (Social SCIENCES Edition) 68 (May, 2014).
} 
safeguard the security of the financial market. One of the incorporations is the sharing of information among all market supervisors.

Meanwhile, the records of a company could be used as the standard of its business credibility. When related information is open to the public, records like tax payments will indicate the reliability of certain companies. For the investors, such kind of information is very practical, and will increase the security of investments.

\section{A Specified Tax Rate of Online Finance}

As a new platform, the online finance is meaningful to the social economy. The designation of the tax rate of online finance should take considerations of the following two aspects: First, the online finance company has the legal obligations of tax payment, which is identical with the other market players ${ }^{5}$. Tax, like company and personal income tax or the deed tax, shall be burdened by the online finance company legally. Second, in order to provide more practical means to finance the small and the agricultural business, government could implement tax incentives to ensure that the online finance company would deliver more market demanded investments.

Because the Chinese Tax Law does not have detailed provisions on the online finance, possible amendments should have the calculations of telecommunication network usage costs. As mentioned before, telecommunication networks expansion has subsidized the online industry. At the same time, the online finance company has strong capacity to collect the information of its customers, which will ensure the security of investments and increase the business profits at last. Tax rate, therewith, shall cope with the characters of online industry.

\section{CONCLUSION}

Online finance is a challenge to the market regulation and also to the tax system. The related reforms and top designs shall be based on the concrete analysis of the economic and physical characters. There are several preconditions of the security of online finance; efficient market regulation could also be provided, when all market regulators and supervisors will share information to the others and be incorporative with the others. Provisions of the tax rate of online finance must coordinate with the proposal that online finance should serve the real.

\footnotetext{
${ }^{5}$ Yang Liu, On the Possibility to Replace Ladder-type Price with Electricity Consumption Tax, 12(1) JOURNAL OF NANJING UNIVERSITY OF TECHNOLOGY 56 (2013).
} 